\title{
An investigation into the eating behaviours of adult patients with Type 1 diabetes using continuous subcutaneous insulin infusion therapy compared to those using multiple daily injections
}

\author{
R.J. Webb ${ }^{1}$, I.G. Davies ${ }^{1}$, T.S. Purewal ${ }^{2}$, P.J. Weston ${ }^{2}$, G. Morrison ${ }^{2}$ and J.C. Abayomi ${ }^{1}$ \\ ${ }^{1}$ Liverpool John Moores University, Faculty of Education, Health \& Community, Barkhill Road, Liverpool, L17 6BD \\ and ${ }^{2}$ Royal Liverpool and Broadgreen University Hospital, Prescot Street, Liverpool, L7 8XP
}

Multiple daily injections (MDI) are an intensive method of administering an external source of basal and bolus insulin for patients with Type 1 diabetes (T1D). This therapy requires 4-5 injections per day, is regarded as an effective method of achieving glycaemic control and is commonly used. If $\mathrm{HbA}_{1 \mathrm{c}}$ remains above $8.5 \%$ or if a patient is experiencing disabling hypoglycaemic episodes continuous subcutaneous insulin infusion (CSII) therapy may be recommended ${ }^{1}$. CSII provides flexible insulin administration via a small, electronic pump unit and has been associated with various benefits when compared to MDI, including increased glycaemic control, reduced occurrence of hypoglycaemia and improvements in the dawn phenomenon ${ }^{1,2}$. Furthermore, the flexible nature of CSII potentially allows patients to enjoy a liberalised diet compared to those using the relatively structured MDI regime ${ }^{2}$. There is a dearth of evidence focussing on the eating behaviours of these patients and research into this area would be useful to inform both treatment and the evaluation of risk.

Following ethical approval and informed consent patients with T1D using either CSII or MDI from the Royal Liverpool Hospital were asked to complete an EPIC-Norfolk food frequency questionnaire (FFQ). Responses were processed using FETA software and demographic data from participants' medical records were added. All data were initially analysed using descriptive statistics. Any data not normally distributed were transformed logarithmically and $t$-tests and Mann-Whitney- $U$-tests were then carried out.

Table 1. Selected FFQ results from patients using CSII and MDI compared to reference nutrient intakes ${ }^{3,4}$

\begin{tabular}{|c|c|c|c|c|c|c|}
\hline Nutrient & $\begin{array}{l}\text { Amount per day } \\
\text { (CSII group) }\end{array}$ & $\begin{array}{l}\text { Amount per day } \\
\text { (MDI group) }\end{array}$ & $\begin{array}{l}\% \text { energy intake per } \\
\text { day (CSII group) }\end{array}$ & $\begin{array}{l}\% \text { energy intake per } \\
\text { day (MDI group) }\end{array}$ & RNI (per day) & $\begin{array}{l}\text { RNI (\% energy } \\
\text { intake per day) }\end{array}$ \\
\hline Energy & $1702 \cdot 0 \mathrm{Kcal}$ & $1886.4 \mathrm{Kcal}$ & N/A & N/A & $2550 \mathrm{Kcal}$ (Males) $1940 \mathrm{Kcal}$ (Females) & N/A \\
\hline Protein & $79 \cdot 0 \mathrm{~g} /$ day & $89.7 \mathrm{~g} /$ day & $18 \cdot 6$ & $19 \cdot 0$ & $55.5 \mathrm{~g} /$ day (males) $45.5 \mathrm{~g} /$ day (females) & 15 \\
\hline Total CHO & $198.7 \mathrm{~g} /$ day & $213.6 \mathrm{~g} / \mathrm{day}$ & $43 \cdot 7$ & $42 \cdot 4$ & N/A & 50 \\
\hline Total sugars & $100 \cdot 7 \mathrm{~g} /$ day & $96 \cdot 0 \mathrm{~g} /$ day & $22 \cdot 2$ & $19 \cdot 1$ & $70 \mathrm{~g} /$ day (males) $50 \mathrm{~g} /$ day (females) & $5 \%$ \\
\hline Total fat & $67.6 \mathrm{~g} /$ day & $76.4 \mathrm{~g} /$ day & $35 \cdot 7$ & $36 \cdot 4$ & N/A & 35 \\
\hline Saturated fat & $25 \cdot 7 \mathrm{~g} /$ day & $27.9 \mathrm{~g} /$ day & $13 \cdot 6$ & $13 \cdot 3$ & N/A & 11 \\
\hline
\end{tabular}

The study population consisted of 60 patients (33.3 \% male, $66.7 \%$ female) with 40 using CSII and 20 using MDI and a mean age of $48 \pm 16$ years. The majority of patients were overweight or obese $(71.4 \%$ CSII, $57.1 \% \mathrm{MDI})$, however energy intake was below the reference nutrient intake (RNI) for both CSII and MDI groups. Patients using both CSII and MDI consumed protein above the RNI for males and females ${ }^{3}$. Despite this protein contributed towards $18.6 \%$ of the daily energy intake of patients using CSII and $19.0 \%$ of those using MDI. Total carbohydrate (CHO) consumption was below the RNI of $50 \%$, however it should be noted that consumption of total sugars was above the RNI for males and females in both groups. This may be partly explained by the consumption of fruit which was also higher in those using CSII. Total fat and saturated fat consumption was marginally above the RNI's. There were no statistically significant associations between any variables and the diets of the two populations appear largely homogenous, despite slight deviations of some nutrients from RNI's. Further analysis of total energy, protein and CHO quality is warranted.

1. Department of Health (2007) Insulin Pump Services: Report of the Insulin Pumps Working Group

2. Cummins E. et al. (2010) Health Technology Assessment, 14 1-208

3. COMA (1991) Dietary Reference Values of Food Energy and Nutrients for the United Kingdom

4. WHO (2015) Sugar Intake for Adults and Children 